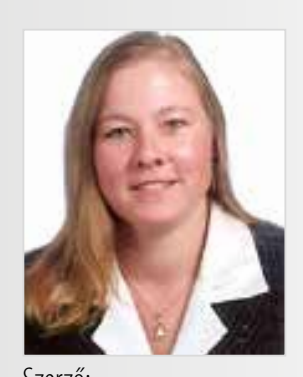

Szerző:

HOJCSKA ÁGNES ERZSÉBET

okleveles fizioterapeuta MSc,

Békés Megyei Központi Kórház; egészségturisztikai tanácsadó, egészségügyi szakértő, Magyar Fürdővárosok Szövetsége; egészségturisztikai tanácsadó, Magyar Fürdőkultúra Kft. h.agnes.erzsebet@gmail.com Tudományos tevékenysége: senior kutató, Fürdővárosok Tudományos Kutatóintézet Főbb kutatási területe: Egészségtudomány: a fizio-balneoterápiás gyógykezelések a mozgásszervi beteg(ség)ek gyógyításában

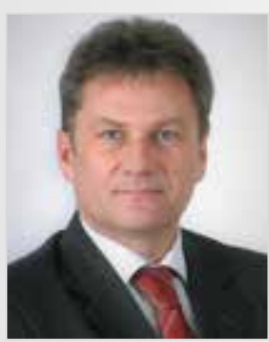

Szerzo":

DR. SZABÓ ZOLTÁN

Pannon Egyetem Georgikon Kar Gazdaságmódszertani Tanszék Területfejlesztési és Menedzsment Csoport

Beosztás: egyetemi adjunktus Levelezési cím: 8360 Keszthely, Deák Ferenc utca 16 szabo.zoltan@georgikon.hu

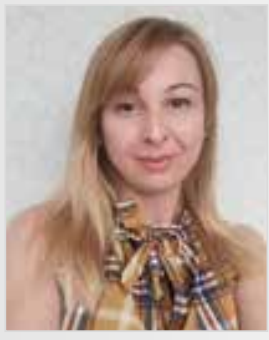

Rovatvezetô:

MATÓ-JUHÁSZ

ANNAMÁRIA

Miskolci Egyetem

Egészségügyi Kar

Whole life balance specialista

efkegtur@uni-miskolchu

egyetemi tanársegéd, Ph.D

hallgató

kutatási terület:

Az egészségtudatos magatartás fejlesztése a társadalmi marketing eszközeivel

\title{
Hidroterápiás fürdốszolgáltatások a rekreációban Hydrotherapy spa services in the recreation
}

\section{2}

Magyarország számos gyógyító és rekreációs kínálattal rendelkezik a gazdag vízbázisra épülő szolgáltatáskínálatának köszönhetően.

Tanulmányunk célja megvizsgálni Magyarországon a különböző típusú fürdők és szolgáltatáskínálatuk változásának trendjeit, továbbá elemezni a hidroterápiás eljárások gyógyászati és rekreációs célú igénybevételi különbségeit a finanszírozás alapján az elmúlt közel egy évtizedben.

Eredményeink azt mutatják, hogy a vizsgált időszakban jelentősen emelkedett a fürdők száma, de fürdőtípusonként eltérő mértékben. Legnagyobb mértékben a rekreációs szolgáltatásokat nyújtó fürdők száma emelkedett. A szolgáltatások igénybevételét tekintve a vizsgált időszakban a Nemzeti Egészségbiztosítási Alapkezelő (NEAK) által támogatott kezelések igénybevételének trendje csökkent, míg az önfinanszírozott egészségmegőrző (wellness) rekreációs szolgáltatásoké növekedett.

A fürdőszolgáltatások és igénybevételük időbeli változásainak és trendjeinek tudományos megalapozottsággal feltárt új eredményei segítséget nyújthatnak az érintett szakterületek szakemberei és döntéshozói számára a fürdők és szolgáltatáskínálatuk fejlesztéseinek tervezésében.

Kulcsszavak: fürdőgyógyászat, fürdőszolgáltatások, hidroterápia, rekreáció, víz
ABSTRACT: Hungary has many healing and recreational service-offering, thanks to the rich water based service-offering. Aim of our study to examine the trends of the different types of spas and their sevices-offering in Hungary. Furthermore, to analyse the differences the recourse hydrotherapy procedures for medical and recreatiaonal purposes in the past near one decade. Our results shows that the number of spas increased significantly during the study period, but different extent by bath type. The number of spas providing the recreational services increased the most. During the study period the use of services the trend reduced in the use of treatments suppported by the National Health Insurance Fund, while the self-financed, health care, recreational services-offering grew. Our new scientific findings on trends in spa services and their use may help for professionals and decision-makers in to planning the spas and spa services-offerings and to develpomnet.

Keywords: bath medicine, hydrotherapy, recreation, spa services, water

\section{Bevezetés}

Napjaink rohanó világában az egészség megőrzéséhez, fenntartásához feltétlenül hozzátartozik a szabadidő hasznos és feltöltődést biztosító eltöltése. Fontos, hogy a mindennapi kötelezettségeken túl az emberek diszkrecionális szabadidejükben elegendő időt fordítsanak a napi fáradtság csökkentésére, mely hozzájárul a testi-lelki jóllét állapotához. Érdemes továbbá szem előtt tartani Dumazedier (1967) megállapítását, akit idéz Fritz és mts. (2007), mely szerint nem életszerú mereven elkülöníteni a szabadidőt, valamint a társadalmi és fiziológiai szükségletekre fordított időt. Mindezek megvalósítására az egyik legjobb, a számos formában rendelkezésre álló rekreáció, mely a szabadságérzeten túl jelentős közérzetjavító hatást is biztosít az embereknek (Ábrahám - Bárdos, 2014). Napjainkban sokféle lehetőség és közeg biztosított a rekreációhoz, melyek közül az egyik nagyon fontos elem a víz. Magyarországon különösen fontos szerepe van a víznek, az ország hidrogeológiai helyzetének köszönhetően. Ennek következtében hazánkban egyaránt elterjedt a hidroterápiás szolgáltatások gyógyító és rekreációs célú használata. Ezeknek a szolgáltatásoknak a széles körű elterjedéséhez hozzájárultak az egészségturizmus tudatos, fenntartható fejlesztését célzó, az előző évtizedben végbement fürdőfejlesztések megvalósítását elősegítő kormányzati intézkedések, mint például a 2005-ben elfogadott Nemzeti Turizmusfejlesztési Stratégia és Országos Területfejlesztési Koncepció, az Új Magyarország program, 2006-2009-ig a Müemlékfürdők Fejlesztése, valamint 2010-tôl az Új Széchenyi Terv (Szabó, 2015).

Tanulmányunk fô célja, a hazai fürdőkínálat és szolgálta- tás-igénybevételének differenciált módon történő feltárása a 2010-2018 közötti időszakban a gyógyászat és a rekreáció vonatkozásában. Az időbeli öszszehasonlítások és változások megismerése segítséget nyújthat az érintett szakterületek szakemberei számára a fürdők és szolgáltatáskínálatuk fejlesztésének tervezésében.

\section{A víz jelentősége}

A Földön megtalálható vegyületek közül a víz előfordulása a leggyakoribb. A földfelszín 70\%-át tengerek borítják, míg az édesvizek összességében 2,3\%-ot tesznek ki, beleértve a kőzetekben megkötött vizeket, a szárazföldek és az óceánok jegét, a kőzetek repedéseiben lévő vizeket és a felszíni édesvizeket is. Az édesvíz 98\%-a felszín alatti vízkészletben található. A víz a földi élethez nélkülözhetetlen, melyet mi sem bizonyít jobban, mint az, hogy az 
emberi test víztartalma 55-95\%, mely mennyiség függ az életkortól, a nemtől és a tápláltságtól (Kádár, 2006). A víz ősidők óta fontos közeg az ember számára, mint például a tisztálkodásban, a tisztításban, a gyógyításban, az egészségi állapot helyreállításában és az egészség megőrzésében. Az egészség fenntartásához elengedhetetlen a testi-lelki jóllét megléte, melyhez jelentősen hozzájárulnak a szellemi (Magyar, 2019) és a fizikai, vagy mozgásos rekreációs tevékenységek, melyek a napi fáradtság csökkentésére alkalmasak (Fritz, 2006), valamint speciális esetekben a terápiás rekreáció is ezt a célt szolgálja (Fritz 2019). A víz alapvető közeget biztosít a rekreációs eljárásokhoz (Magyar, 2016), melyek megvalósítására kiemelkedő lehetőségek állnak rendelkezésre Magyarországon.

A vízminőséget az egyre növekvő számú gyógyvízkutatások eredményei bizonyítják (Mayer - Hojcska 2019). A mennyiségi mutatók tekintetében pedig Magyarország a világon az ötödik helyet foglalja el termálvízkészletével Japán, Izland, Olaszország és Franciaország mögött (Csermely, 2009).

\section{Módszerek}

A kitűzött fő kutatási célunk eléréséhez a 2010-2018 közötti időszakra vonatkozólag három részcélt határoztunk meg. Az első részcélunk volt a hazai fürdőtípusok mennyiségi változásának és azok tendenciáinak vizsgálata. Második részcélunk a fürdőszolgáltatások számának változásvizsgálata volt a gyógyító és a rekreációs célú eljárások vonatkozásában. Harmadik részcélunk pedig a fürdők látogatóforgalmának összesített vizsgálata volt, valamint elemzeni a fürdőszolgáltatásokat a finanszírozás szempontjából, vagyis a gyógyászati (NEAK által támogatott) és a rekreációs (önfinanszírozott) szolgáltatás-igénybevételt.

A részcélok elérése érdekében, valamint az információk gyors és költséghatékony megszerezhetősége érdekében a kvantitatív kutatási módszerek közül a szekunder kutatást választottuk. A kutatás a Központi Statisztikai Hivatal $(K S H)$ jelenleg elérhető legfrissebb hivatalos statisztikáira épült a 2010-2018 közötti időszakra vonatkozóan. Az adatgyüjtést hét fürdőkategóriában végeztük fürdő, strand, uszoda, tanuszoda és egyéb fürdő. A legyüjtött statisztikai adatok jellegzetességeit figyelembe véve, valamint azok komplex módon való vizsgálata érdekében többféle leíró statisztikai módszer került alkalmazásra. A trendek meghatározását nehezítette az adatok ingadozó állapota, ezért a pontos trendmeghatározáshoz a legkisebb négyzetek módszere alapján polinomiális trendszámítást végeztünk. Ennek során figyelembe vettük a determináltsági együttható (R2) értékét, mely akkor utal a legmegbízhatóbb trendvonalra, ha értéke 1, vagy 1-hez közelít. A fürdőszolgáltatások finanszírozás (7/2012. (VI. 29.) EMMI rendelet egyes egészségbiztosítási tárgyú miniszteri rendeletek módosításáról) szerinti igénybevételi változásának meghatározásához pedig a bázisviszonyszám számítási eljárást alkalmaztuk. Ehhez a vizsgált időszak első évének (2010) adatait tekintettük bázisadatnak (100\%), melyhez a vizsgált időszak utolsó évének (2018) adatait (tényadatok) viszonyítottuk, továbbá a jelentős eltérések esetén a köztes időszakok is elemzésre kerültek. A bázisviszonyszám kiszámításához az alábbi képletet használtuk: Vb\% = Tényadat/Bázisadat x 100 (Babbie 2017).

A statisztikai elemzések során az időbeli összehasonlítások és az időbeli változások vizsgálata segíti az elmúlt időszak tendenciáinak, valamint összefüggéseinek feltárását. el: gyógyfürdő, termálfürdő, élmény-

\section{Eredmények}

Magyarország a jelentős mennyiségi és minőségi vízkészlete alapján termál- és gyógyvíznagyhatalom. Ennek köszönhetően számos fürdő található országunkban, melyek száma évről évre változik. A hazai hidroterápiás eljárások vizsgálatával egyrészt az egyes fürdőtípusok és szolgáltatáskínálatuk változására, másrészt a fürdők látogatóforgalmi különbségeire tértünk ki.

\subsection{Magyarországi fürdőtípusok számának változása}

Az első részcélunk elérése érdekében megvizsgáltuk a hazai fürdőtípusok számának változását és azok tendenciáit. Magyarországon a 20102018 közötti kilenc évben hétfajta fürdőtípus biztosította a hidroterápiás eljárásokat a látogatók számára. A kilenc év adatsorából jól látható, hogy a különböző szolgáltatók száma eltérő mértékben és egyenetlenül változott a különböző fürdőtípusok között (1. ábra).

Annak érdekében, hogy a különböző fürdőtípusok közül kiszürjük a rekreációs szolgáltatásokat nyújtókat, két csoportba osztottuk a fürdőket. Az egyik csoportba a gyógyfürdők kerültek, melyek döntően gyógyászati szolgáltatásokat biztosítanak, a másik csoportba pedig a további hat fürdőtípus került, melyek rekreációs céllal állnak a látogatók rendelkezésére.

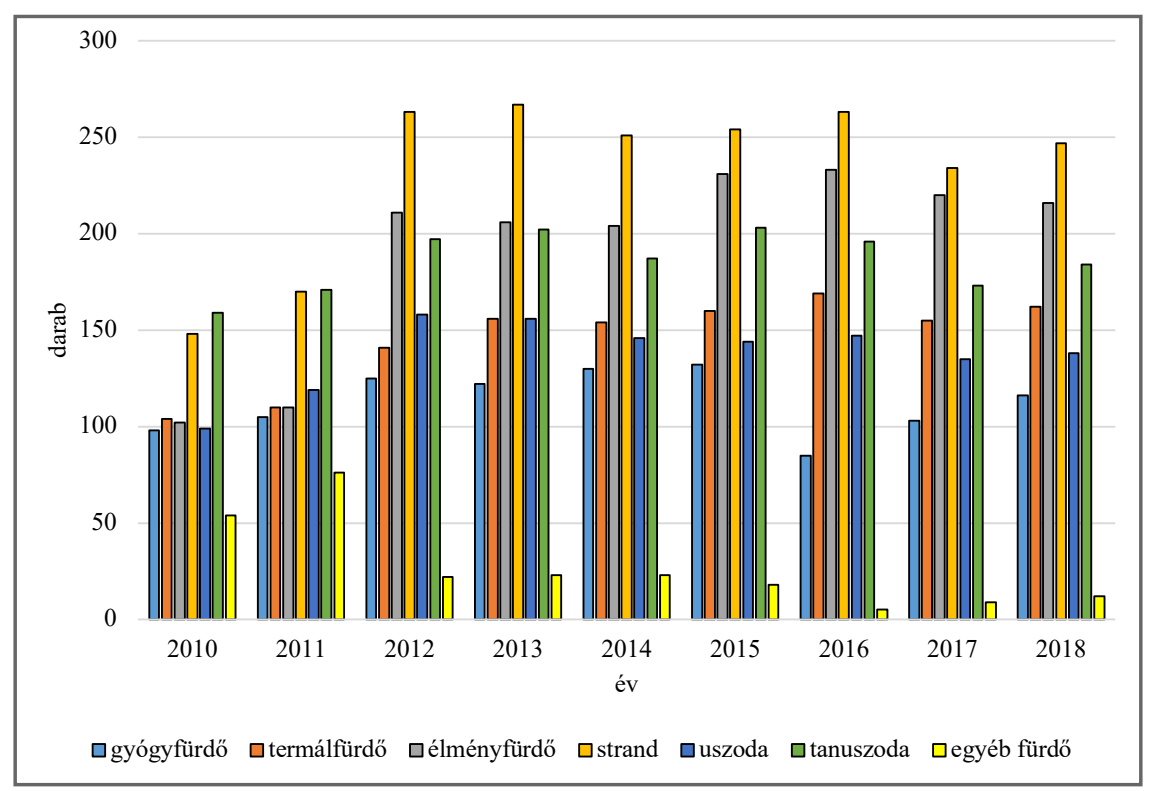

1. ábra: Magyarországi fürdők számának változása típusonként 2010-2018 között Forrás: KSH-adatok alapján, saját szerkesztés 
Ezen fürdőcsoport megnevezésére bevezettük a „rekreációs fürdők” elnevezést. A továbbiakban a gyógyfürdők és a rekreációs fürdők számának változása külön került elemzésre.

\subsubsection{Gyógyfürdők hidroterápiás szolgáltatásokkal}

Először a gyógyfürdők számának változását vizsgáltuk meg 2010-2018 között. Ezt a változást és trendet a 2. ábra szemlélteti.

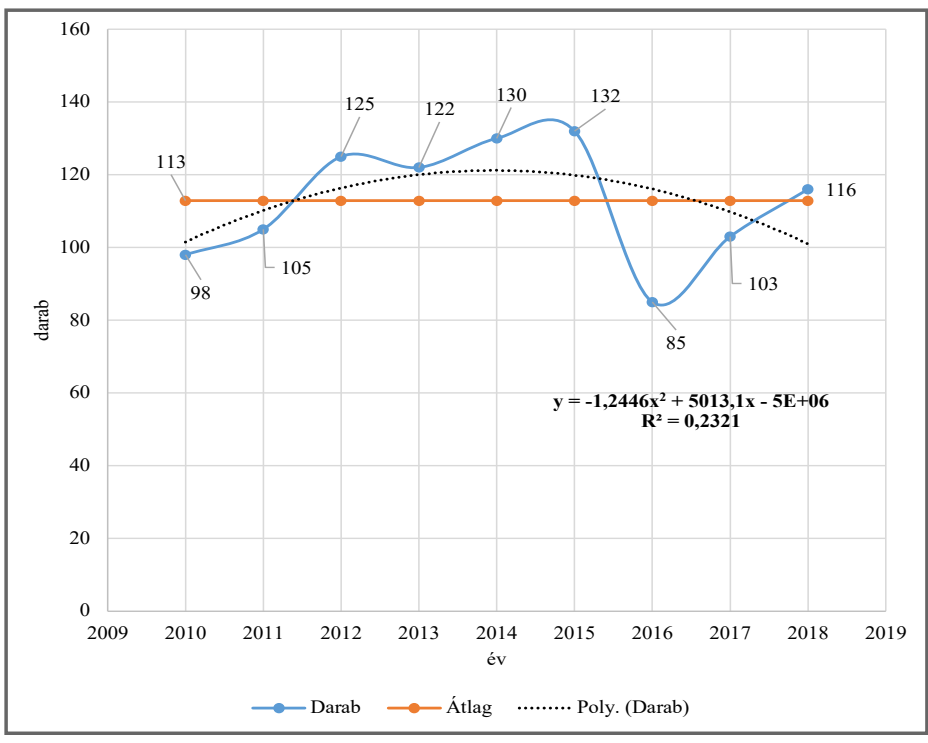

2. ábra:

A gyógyfürdők számának változása 2010-2018 között Forrás: KSH-adatok alapján, saját szerkesztés

A vizsgált időszakban a gyógyfürdők száma 85-132 darab között változott. A gyógyfürdők átlaga 113 darab volt a vizsgált időintervallumban. Az első évében 13\%-kal volt kevesebb gyógyfürdő az átlagnál. A fürdők mennyisége 2012-ig folyamatosan emelkedett, és így számuk ebben az évben 11\%-kal haladta meg az átlagot. Ezt 2013-ban 8\%-os csökkenés követte, majd a további évek folyamatos fürdőszám-emelkedésének köszönhetően 2015-ben elérte a vizsgált időszak maximumát, amikor 17\%-kal volt az átlag felett. A 2016-os évben, az előző évhez viszonyítva egy jelentős, 25\%-os fürdőszámcsökkenés következett, majd 2018ig ismét emelkedés, de így is csak 3\%-kal haladta meg az átlagot. Ez azt jelenti, hogy 2012-2015-ig a gyógyfürdők száma átlag feletti, a többi évben pedig átlag alatti volt. Ennek a váltakozásnak köszönhetően ingadozó adatokkal rendelkezünk, ezért a gyógyfürdőszámok trendjének pontos meghatározásához a polinomiális trendszámítást alkalmaztuk. A kapott determináltsági együttható $(R 2=0,2321)$ értéke alapján a trendvonal nem tekinthető megbízhatónak, ezért a trend nem került további elemzésre.

\subsubsection{Rekreációs fürdök hidroterápiás szolgáltatásokkal}

A gyógyfürdők számának elemzése után megvizsgáltuk a rekreációs fürdők ugyanezen adatainak alakulását a 2010-2018 közötti időszakban. Ezt a változást és trendet a 3. ábra szemlélteti.

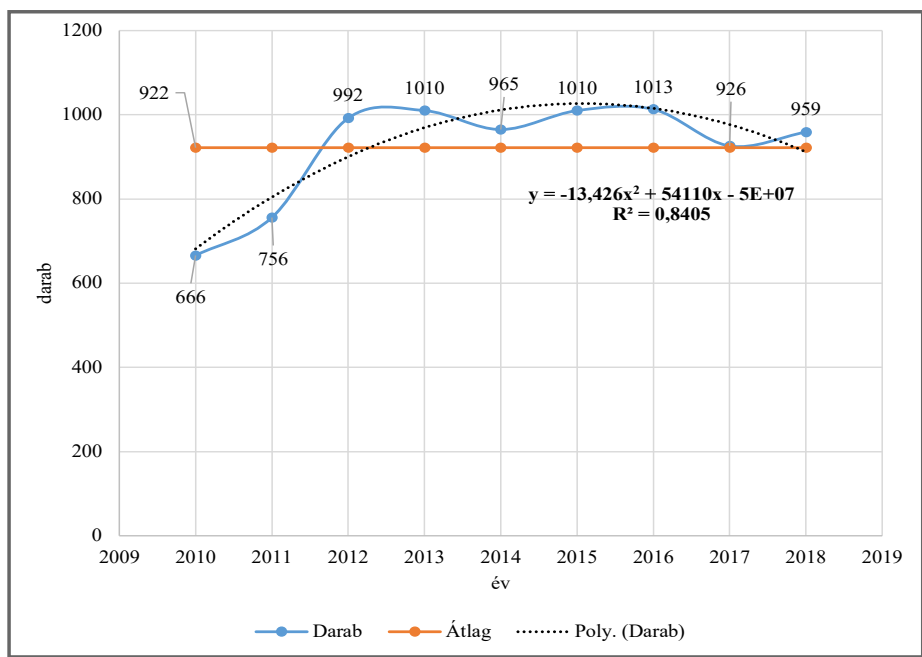

3. ábra:

A rekreációs fürdők számának változása 2010-2018 között

Forrás: KSH-adatok alapján, saját szerkesztés

A vizsgált időszakban a rekreációs fürdők száma 6661013 darab között változott. Ez átlagosan 922 darabot jelent a vizsgált időszakban. Az első évben Magyarországon 28\%-kal az átlag alatti számban üzemelt rekreációs fürdő, mely adat folyamatosan emelkedett 2013-ig, amikor már 10\%-kal az átlag fölött volt. A következő évben 5\%-os csökkenés következett be, de ezután 2016-ig ismét emelkedés volt tapasztalható. A rekreációs fürdők száma ebben az évben az átlaghoz viszonyított 10\%-os emelkedéssel a vizsgált időszak maximumát érte el, mely a következő évi csökkenés miatt az azt követő 2018. évi 4\%-os emelkedéssel sem érte el újra a vizsgált időszak maximumát. Megállapítható, hogy a 2010-2011. év kivételével a rekreációs fürdők száma a többi évben átlag feletti volt. A rekreációs fürdők száma ingadozást mutatott a vizsgált időszakban, ezért trendjét legpontosabban a polinomiális trendszámítás alkalmazásával tudtuk meghatározni. Az így kapott determináltsági együttható $(R 2=0,8405)$ értéke alapján a trendvonal megbízhatónak tekinthető, ezért azt tovább elemeztük. A trendvonal a vizsgált időszak kezdetétől 2014-ig dinamikus növekedést mutatott, majd 2016-ig stagnáló trendet követett, ezt követően pedig csökkenést mutatott a vizsgált időszak végéig.

\subsection{Fürdőszolgáltatások a fürdőkben}

Második részcélunk eléréséhez a gyógyító és a rekreációs célú fürdőszolgáltatások számának változásvizsgálatát végeztük el. Ennek érdekében a fürdők csoportosításához hasonlóan a fürdőszolgáltatás-kínálatot is két nagy csoportba osztottuk. Az egyik csoportot a gyógyászati kezelések (NEAK) támogatott típusai, a másik csoportot pedig az egészségmegőrző (wellness) szolgáltatások adták, melyeket rekreációs céllal vesznek igénybe a fürdőlátogatók. Napjainkban ugyanis a gyógyászati kezelések mellett egyre több lehetőség nyílik a látogatók számára valamilyen vizes eljárás igénybevételére kikapcsolódási céllal, valamint a rekreáció révén az egészség megőrzésére és a prevencióra egyaránt. Mindezt a fürdők gyógykezelési eljárásain túl a bővülő szolgáltatáskínálatuk tette lehetővé (4. ábra). 


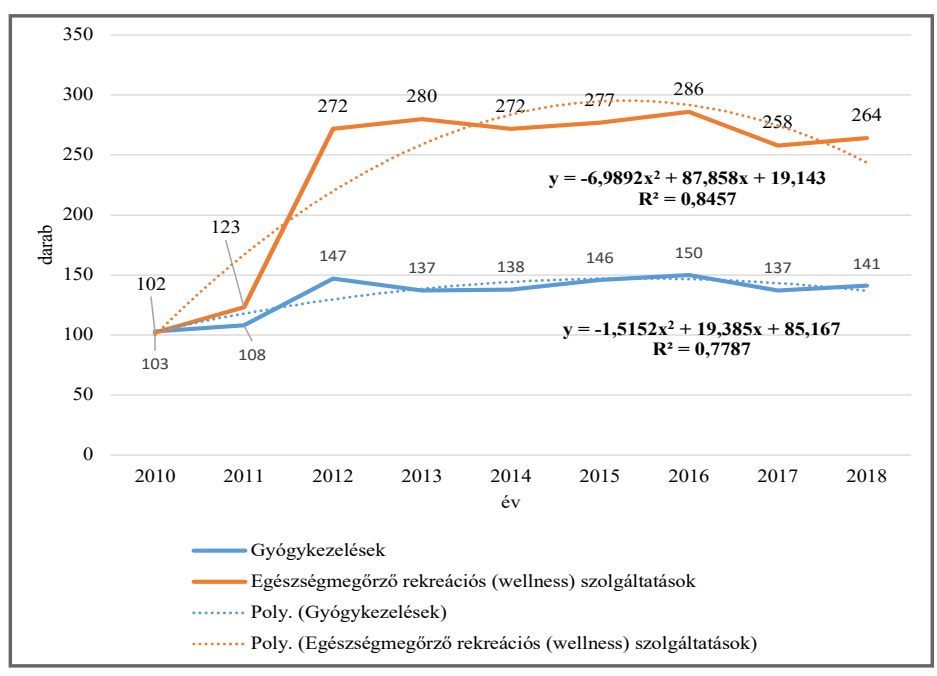

4. ábra:

A fürdőszolgáltatások számának változása

Forrás: $\mathrm{KSH}$-adatok alapján, saját szerkesztés

Az igénybe vehető fürdőszolgáltatások száma a vizsgált időszak elején közel egyenlő volt a gyógykezelések (103 darab) és az egészségmegőrző rekreációs (wellness) szolgáltatások (102 darab) tekintetében. A gyógykezelések száma 2011-ról 2012-re emelkedett a legnagyobb mértékben (26,53\%). A továbbiakban a 2012-ben elért szolgáltatásszámok voltak a jellemzők, minimális ingadozást mutatva 2016-ig. Ezt követően kismértékủ csökkenés (6\%) volt tapasztalható a gyógyszolgáltatások tekintetében 2018 végére. A gyógyító fürdőszolgáltatások adatai ingadoztak a vizsgált időszakban, ezért a trend pontos meghatározásához a polinomiális trendszámítást alkalmaztuk. A determináltsági együttható $(R 2=0,7787)$ értéke alapján a trendvonal megbízhatónak tekinthető, ezért azt tovább elemeztük. Ennek eredményeként azt kaptuk, hogy a gyógyszolgáltatások trendvonala 2010-tôl 2014-ig egyenletes emelkedést mutatott, majd 2016-ig stagnált, azután pedig a vizsgált időszak végéig leszálló ívet írt le.

Magyarország természeti adottságainak köszönhetően a gyógyvizek alkalmazása az egészségi állapot javításában kiemelkedő. Ezt napjainkban egyre több tudományos klinikai vizsgálat igazolja, melyek bizonyítékul szolgálnak a hazai gyógyvizek gyógyhatására. A hazai gyógyvizek elsősorban a különböző betegségek kezelésében játszanak jelentős szerepet az állami támogatással (NEAK) igénybe vehető tizenegy különböző gyógykezelés segítségével (1. táblázat, 5/2004. (XI. 19.) EüM rendelet alapján).

\begin{tabular}{|l|c|}
\hline $\begin{array}{l}\text { Az egyes gyógyászati ellátások } \\
\text { megnevezése }\end{array}$ & $\begin{array}{c}\text { Aź egyes } \\
\text { gyógyászati } \\
\text { ellátások } \\
\text { kódszáma }\end{array}$ \\
\hline Gyógyvizes gyógymedence & 1 \\
\hline Gyógyvizes kádfürdő & 2 \\
\hline Iszappakolás & 3 \\
\hline Súlyfürdő & 4 \\
\hline Szénsavas fürdő & 5 \\
\hline Orvosi gyógymasszázs & 6 \\
\hline Víz alatti vízsugármasszázs & 7 \\
\hline Víz alatti csoportos gyógytorna & 8 \\
\hline Komplex fürdőgyógyászati ellátás & 9 \\
\hline 18 éves kor alatti csoportos & 10 \\
\hline gyógyúszás & 11 \\
\hline Szén-dioxid gyógygázfürdő &
\end{tabular}

A táblázatban szereplő eljárások (a o6-os és 11-es kódú kezeléstípusok nem hidroterápiás eljárások, de a NEAKtámogatott szolgáltatások részét képezik) elsősorban gyógykezelésként állnak a gyógyulni vágyók rendelkezésére, de kutatási eredményeink jól mutatják, hogy hazánk vízkészlete a betegségek kezelésére szolgáló gyógyszolgáltatásokon túl számos egyéb hidroterápiás eljáráshoz biztosít megfelelő közeget. Ezek a testi-lelki egyensúly kialakításán keresztül az egészségmegőrzés fontos részét képezhetik, beépítve azokat az emberek szabadidős és rekreációs tevékenységi körébe.

Az egészségmegőrző rekreációs (wellness) szolgáltatások száma a gyógyszolgáltatások számához hasonlóan 2012-re mutatott jelentős emelkedést (54,78\%). Ezt az évet követően 2013-ra még 3\%-kal emelkedett a rekreációs szolgáltatások száma, majd 2014-re visszaesett a 2012. évi szintre. Ezután 2016-ig mindösszesen 5\% emelkedés volt tapasztalható, majd 2017-re 11\%-os szolgáltatószámcsökkenés volt mérhető. 2018-ra azonban ismét enyhe (2\%) növekedés történt. Az egészségmegőrző rekreációs (wellness) szolgáltatások számának trendmeghatározásánál is a polinomiális trendszámítást használtuk, mert itt is ingadozó adatokat kaptunk. A determináltsági együttható $(R 2=0,8457)$ értéke alapján a trendvonal megbízhatónak tekinthetó, ezért tovább vizsgáltuk az adatokat. A trendvonal alapján megállapítható, hogy 2010-től 2015-ig intenzív a szolgáltatószám-növekedés, majd a vizsgált időszak végéig csökkenés mutatkozott az egészségmegőrző rekreációs (wellness) szolgáltatások számának trendjében.

\subsection{Fürdőszolgáltatások kereslete a fürdőkben}

A harmadik kutatási részcélunk elérése érdekében elvégeztük a fürdők látogatóforgalmának vizsgálatát a fürdőszolgáltatások igénybevételének finanszírozási szemszögéből. Külön elemeztük a NEAK által támogatott gyógyászati és az önfinanszírozott, vagyis rekreációs céllal történő igénybevételek arányát.

A Magyarországon megtalálható fürdők többségében lehetőség van a szolgáltatásokat önfinanszírozottan és bizonyos típusaikat állami támogatással (NEAK) is igénybe venni. A KSH adatai alapján megállapítást nyert, hogy a fürdők szolgáltatásait 2010-től 2018-ig egyre nagyobb számban vették igénybe a fürdőlátogatók (5. ábra).

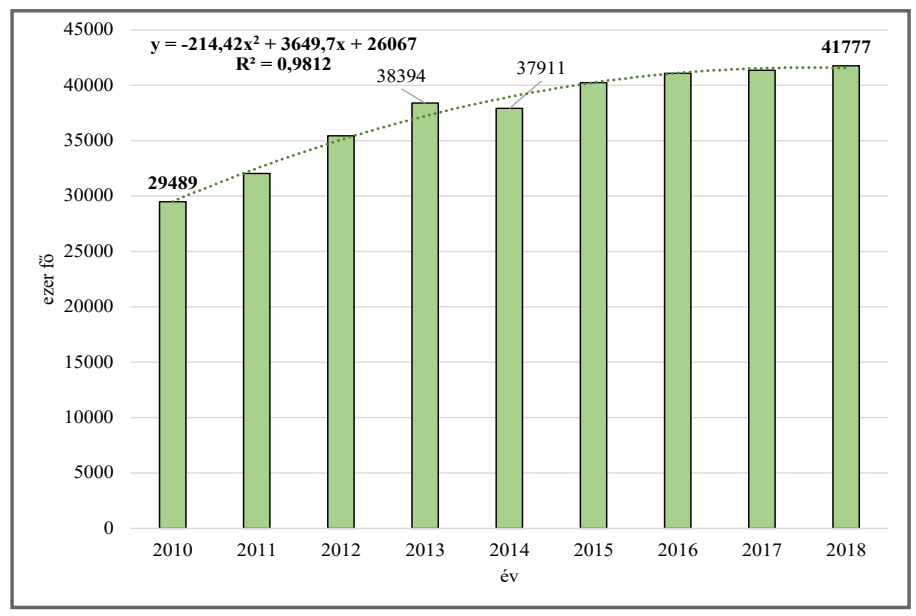

5. ábra:

A fürdők látogatóforgalma összesen (ezer fö)

Forrás: KSH-adatok alapján, saját szerkesztés 
Az adatokból jól látszik, hogy a 2014. évi kismértékű visszaesésen kívül minden évben emelkedést mutatott a fürdőszolgáltatásokat igénybe vevők száma, de egyenlőtlen mértékben. Megvizsgáltuk, hogy a vizsgált időszak kezdetétől milyen mértékű változás ment végbe az időszak végéig. A vizsgált időszak bázisidőpontjában lévő látogatóforgalom (29 489 ezer fö) az időszak végére (41 777 ezer fó) 42\%-os növekedést eredményezett.

A fürdők látogatóforgalmi trendjének megállapításához a polinomiális trendszámítást alkalmaztuk. A determináltsági együttható $(R 2=0,9812)$ értéke alapján a trendvonal megbízhatónak tekinthető, ezért tovább elemeztük az adatokat. Ez alapján a trendvonal minimuma 2010-ben 29489 ezer fö, a maximuma pedig 2018-ban 41777 fö volt. A trendvonal a vizsgálati idő kezdetétől 2016-ig dinamikusan emelkedett, majd a vizsgált időszak végéig egyre lassuló növekedésű látogatóforgalmat mutatott.

A továbbiakban megvizsgáltuk, hogy a fürdőszolgáltatásokat milyen arányban veszik igénybe a látogatók államilag (NEAK) támogatottan gyógyászati és önfinanszírozott formában rekreációs céllal.

\subsubsection{Gyógyászati célú látogatóforgalom}

A fürdők látogatóforgalmát először a gyógyászati célú igénybevételhez viszonyítva elemeztük (6. ábra).

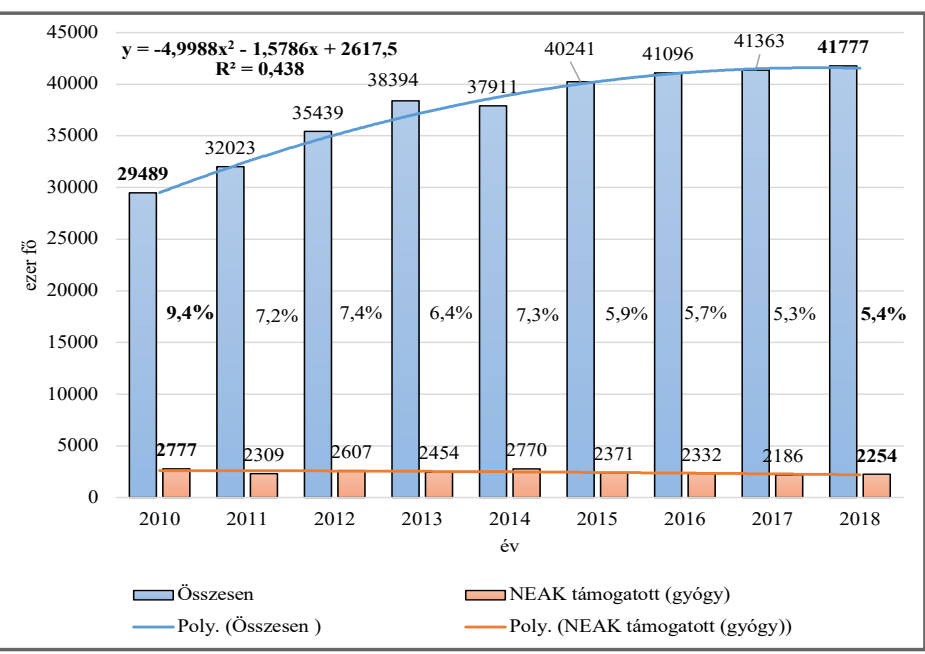

6. ábra: A fürdők összes és a NEAK-támogatott (gyógy) látogatóforgalma (ezer fö)

Forrás: $K S H$-adatok alapján, saját szerkesztés

A fürdők összes látogatóforgalmának átlaga a vizsgált időszakban 37526 ezer fő volt, míg a NEAK-támogatással igénybe vett (gyógyászati) szolgáltatásokat igénybe vevők látogatóforgalmának átlaga 2451 ezer fő volt. A fürdők összes látogatóforgalmához viszonyítva a NEAK-támogatással igénybe vett (gyógyászati) szolgáltatásokról megállapítható, hogy az minden évben meghaladta az 5\%-ot, de egyik évben sem érte el a 10\%-ot. Ezekből az adatokból látszik, hogy a gyógykezeléseket igénybe vevők száma csak töredékét tette ki a fürdők összes látogatóforgalmának.

Megvizsgáltuk, hogy a vizsgált időszak kezdete és vége között milyen változás ment végbe a gyógykezeléseket nyújtó fürdők látogatóforgalmi adatai között. A vizsgált időszak bázisidőpontjában lévő látogatóforgalom (2777 ezer fö) az időszak végére (2254 ezer fö) 19\%-os csökke- nést eredményezett. A gyógyfürdők látogatóforgalmának trendmeghatározásához az ingadozó adatok miatt ebben az esetben is a polinomiális trendszámítást alkalmaztuk.

A kapott determináltsági együttható $(R 2=0,438)$ értéke alapján a trendvonal nem tekinthető megbízhatónak, ezért a trend nem került elemzésre.

\subsubsection{Rekreációs célú látogatóforgalom}

A fürdők látogatóforgalmát az önfinanszírozott, rekreációs célú igénybevételhez viszonyítva is elemeztük (7. ábra).

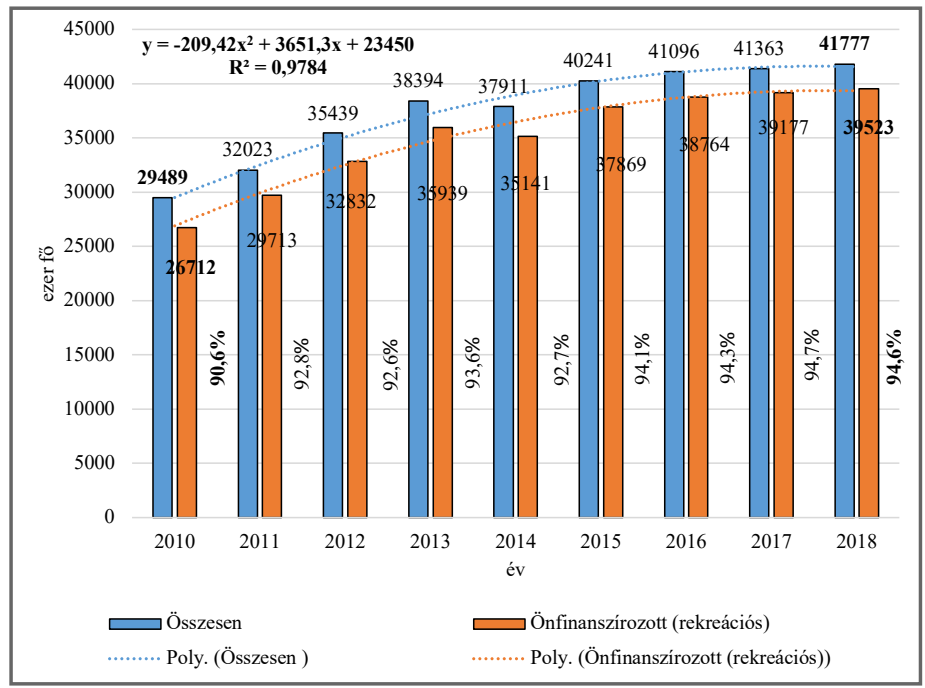

7. ábra: A fürdők összes és önfinanszírozott (rekreációs)

látogatóforgalma (ezer fö)

Forrás: KSH-adatok alapján, saját szerkesztés

A fürdők összes látogatóforgalmának átlaga a vizsgált időszakban 37526 ezer fő volt, míg az önfinanszírozott (rekreációs) szolgáltatásokat igénybe vevők látogatóforgalmának átlaga 35075 ezer fő volt.

Ezekből az adatokból látszik, hogy az önfinanszírozott (rekreációs) vizes szolgáltatásokat igénybe vevők száma tette ki a többségét a fürdők összes látogatóforgalmának. A fürdők összes látogatóforgalmához viszonyítva az önfinanszírozott (rekreációs) szolgáltatásokról megállapítható, hogy az minden évben meghaladta a 90\%-ot, de egyik évben sem érte el a 95\%-ot.

Megvizsgáltuk, hogy a vizsgált időszak kezdete és vége között milyen változás ment végbe az önfinanszírozott (rekreációs) szolgáltatásokat nyújtó fürdők látogatóforgalmi adatai között.

A vizsgált időszak bázisidőpontjában lévő látogatóforgalom (26 712 ezer fö) az időszak végére (39 523 ezer fö) 48\%-os növekedést eredményezett.

A rekreációs látogatóforgalom trendjének meghatározásához a polinomiális trendszámítást alkalmaztuk. A determináltsági együttható $(R 2=0,9784)$ értéke alapján a trendvonal megbízhatónak tekinthető, ezért tovább elemeztük az adatokat.

A trendvonal 2013-ig intenzívebb, majd 2015-től mérsékeltebb látogatóforgalom-növekedést mutatott. Ez a trendvonal párhuzamosan haladt a fürdők összesített látogatóforgalmi adatainak szintén növekedést mutató trendvonalával. 


\section{Következtetések, javaslatok}

A szakirodalmi adatok azt erősítik meg, hogy a rekreáció térhódítása hozzájárul az egészségi állapot javításához, melynek következtében javulhat az életminőség, a munkavégző képesség, és emelkedhet az egészségben eltölthető évek száma. A kutatási célkitüzésünk megvalósult, és részcéljaink elérésével az alábbi megállapításokat fogalmaztuk meg.

A fürdőtípusok számának és azok változási trendjének vizsgálata során megállapítottuk, hogy a gyógyfürdők száma a vizsgált kilenc év során négy évben átlag (113 darab) felett, öt évben pedig átlag alatt alakult, míg a rekreációs fürdők száma két év kivételével átlag (922 darab) feletti volt. Ezekből az adatokból az következik, hogy a vizsgált időszakban átlagosan több mint nyolcszoros volt a rekreációs fürdők száma a gyógyfürdők számához képest.

A fürdőszolgáltatások számát tekintve megállapítást nyert, hogy a gyógykezelések száma ingadozó volt 20102018 között. Trendjét tekintve ennek a szolgáltatástípusnak a változása 2014-ig emelkedő, majd 2016-ig stagnáló és 2018-ig pedig csökkenő tendenciát mutatott. Ezzel szemben a rekreációs, egészségmegőrző (wellness) szolgáltatások trendje 2015-ig jelentős mértékben emelkedett, majd a vizsgált időszak végéig csökkenő trendet követett.

A fürdőszolgáltatások látogatóforgalmát tekintve öszszességében 42\%-os igénybevétel-növekedés volt tapasztalható a vizsgált időintervallumban, de jelentős különbségeket mutatva a gyógy- és rekreációs célú felhasználást illetően. Az igénybe vett gyógykezelések száma az összes fürdőszolgáltatás-igénybevételnek kevesebb mint 10\%-át, a rekreációs szolgáltatások pedig több mint 90\%-át adták a vizsgált időszakban. Míg a gyógykezelések számának igénybevétele 2010 és 2018 között folyamatosan csökkent 9,4\%-ról 5,4\%-ra, addig a rekreációs szolgáltatás-igénybevétel 90,6\%-ról 94,6\%-ra emelkedett 2013-ig intenzív, majd mérsékeltebb ütemben.

A változások időbeli alakulása alapján ezeknek a trendeknek a kialakulásában jelentős szerepük lehetett az elmúlt évtizedben végbement hazai fürdőfejlesztéseknek, melyek hatása az eredményeink alapján 2013-ig tartott. Eredményeink azt mutatják, hogy 2013 után minden vizsgált kategóriában csökkenés, illetve a növekedés mérséklődése tapasztalható. Ebből az következik, hogy a fürdőfejlesztések hatása három-öt évig érzékelhető a hazai fürdők szolgáltatás-igénybevételének vonatkozásában. Ezért a negatív trend megálítására, esetleg annak megfordítása érdekében javasoljuk a folyamatos fürdőfejlesztések stratégiájának tudatos kidolgozását. Továbbá a kapott eredmények alapján javasoljuk a fürdók által nyújtott szolgáltatásokhoz kapcsolódó ismeretterjesztés, valamint az egészségre és rekreációra való nevelés előtérbe helyezését minden korosztály számára. Figyelembe véve azt, hogy az emberek egyre több alkalommal töltik szabadidejüket a fürdők által biztosított, elsősorban rekreációs lehetőségekkel, ezzel is hozzájárulva az egészségük megőrzéséhez. Ezek az eredmények és javaslatok hozzájárulhatnak az érintett szakterületek szakemberei és döntéshozói számára a fürdők célzott szolgáltatáskínálat fejlesztései stratégiáinak megalapozásához.

Anyagi támogatás: A közlemény megírása, illetve a kapcsolódó kutatómunka anyagi támogatásban nem részesült.

Érdekeltségek: A szerzőknek nincsenek érdekeltségeik.

\section{Irodalomjegyzék}

Ábrahám, J., Bárdos, Gy. (2014): Szabadidő és rekreáció Problémafelvetés. Kultúra és Közösség V. évfolyam 2014/I. pp. 25-29.

Babbie, E. (2017). A társadalmi kutatás gyakorlata. Balassi Kiadó, 744 p.

Csermely, M. (2009). Fizioterápia. Budapest, Medicina. $292 \mathrm{p}$.

Dumazedier, J. (1967) Towards a Sociology of Leisure. Macmillan, New York. Free Press.

Fritz, P. (2006): Rekreáció mindenkinek I. Mozgásos rekreáció. Bába Kiadó, Szeged, 368 p.

Fritz, P. (2019): Terápiás rekreáció. In: Fritz, P. (szerk.) Alapfogalmak és jelentéseik a rekreáció területén. Rekreáció mindenkinek III. Miskolci Egyetemi Kiadó, pp. 124-131.

Fritz, P., Schaub, Gné, Hegedüs, I. (2007): Kapcsolat az életmód, szabadidő és rekreáció között. Magyar Sporttudományi Szemle, 2. pp. 52-56.

Kádár, M. (2006). A víz szerepe az élővilágban és a társadalomban. In: Ákoshegyi, Gy., Németh, I.: Fürdők kézikönyve. pp. 82-93.

KSH (2019): A fürdők főbb jellemzői, forgalma és a fürdők által nyújtott szolgáltatások (2010-). http:// www.ksh.hu/docs/hun/xstadat/xstadat_eves/i_ fur001c.html?lang=hu

Magyar, M. (2016): A víz rekreációs és élményközvetítő szerepe. RECREATION: A KÖZÉP-KELET-EURÓPAI REKREÁCIÓS TÁRSASÁG TUDOMÁNYOS MAGAZINJA, 6(2) pp. 39-43. doi: 10.21486/recreation.2016.6.2.3

Magyar, M. (2019): Nem mozgás-dominanciájú rekreáció értelmezési nemzetközi és hazai környezetben. In: Gősi, Zs., Boros, Sz., Pné Bősze, J. (szerk.) Sokszínű rekreáció - Tanulmányok a rekreáció témaköréből. (CEötvös Loránd Tudományegyetem Pedagógiai és Pszichológiai Kar, 140 p. https://esi.ppk. elte.hu

Mayer, Á., Hojcska, Á. E. (2018): A bizonyítékokon alapuló balneo- és hidroterápiás kezelések szerepe a térdartrózis kezelésében. In: Szabó, Z. (szerk.) Fürdővárosok fejlődése. Magyar Fürdővárosok Szövetsége, pp. 147-168.

Szabó, Z. (2015): Fürdőturizmus - városfejlesztés - térségi modernizáció. In: Galambos, I., Michalkó, G., Törzsök, A., Wirth, G. (szerk.) Fürdővárosok. Budapest, pp. 279-289.

5/2004. (XI. 19.) EüM rendelet az orvosi rehabilitáció céljából társadalombiztosítási támogatással igénybe vehető gyógyászati ellátásokról. Többszörösen módosított rendelet.

7/2012. (VI. 29.) EMMI rendelet egyes egészségbiztosítási tárgyú miniszteri rendeletek módosításáról. 4. melléklet a 7/2012. (VI. 29.) EMMI rendelethez. 8. melléklet a 5/2004. (XI. 19.) EüM rendelethez. 